\title{
Classification of Alcaligenes faecalis-like isolates from the environment and human clinical samples as Ralstonia gilardii sp. nov.
}

\author{
Tom Coenye, ${ }^{1}$ Enevold Falsen, ${ }^{2}$ Marc Vancanneyt, ${ }^{3}$ Bart Hoste, ${ }^{3}$ \\ John R. W. Govan, ${ }^{4}$ Karel Kersters ${ }^{1}$ and Peter Vandamme ${ }^{1,5}$
}

Author for correspondence: T. Coenye. Tel: +32926451 14. Fax: +3292645092. e-mail: Tom.Coenye@rug.ac.be

\footnotetext{
1 Laboratorium voor Microbiologie, Universiteit Gent, K. L. Ledeganckstraat 35 , B-9000 Gent, Belgium

2 Culture Collection, Department of Clinical Bacteriology, University of Göteborg, Göteborg, Sweden

3 BCCM/LMG Culture Collection, Laboratorium voor Microbiologie Gent, Universiteit Gent, Belgium

4 Department of Medical Microbiology, University of Edinburgh, Edinburgh, UK

5 Department of Medical Microbiology, University Hospital UIA, Antwerp, Belgium
}

\begin{abstract}
A polyphasic taxonomic study that included DNA-DNA hybridizations, DNA base ratio determinations, 165 rDNA sequence analysis, whole-cell protein and fatty acid analyses, AFLP (amplified fragment length polymorphism) fingerprinting and an extensive biochemical characterization was performed on 10 strains provisionally identified as Alcaligenes faecalis-like bacteria. The six environmental and four human isolates belonged to the genus Ralstonia and were assigned to a new species for which the name Ralstonia gilardii sp. nov. is proposed. The type strain is LMG 5886'.
\end{abstract}

Keywords: Ralstonia gilardii sp. nov., Ralstonia eutropha, taxonomy

\section{INTRODUCTION}

The genus Ralstonia was established by Yabuuchi et al. (1995) to accommodate generically misnamed Burkholderia and Alcaligenes species: Ralstonia pickettii (the type species), Ralstonia solanacearum and Ralstonia eutropha. Ralstonia species occupy very diverse ecological niches. $R$. pickettii strains are isolated from various clinical sources (including urine, nasopharynx, wounds, blood and cerebrospinal fluid) (Riley \& Weaver, 1975) and are responsible for nosocomial infections (McNeill et al., 1985; Verschraegen et al., 1985). $R$. solanacearum is one of the most important bacterial phytopathogenic species (Palleroni \& Doudoroff, 1971), causing bacterial wilt on a wide

Abbreviation: AFLP, amplified fragment length polymorphism.

The GenBank accession number for the fragment of the 16S rRNA gene of Ralstonia gilardii sp. nov. is AF076645. range of crops, including potato, tomato, ginger and banana (Taghavi et al., 1996). Finally, $R$. eutropha is an environmental organism isolated from sludge, soil and waste-water. Its ability to grow autotrophically has received special attention as a potential source of single-cell protein (Jenni et al., 1988).

We performed a polyphasic taxonomic study to elucidate the taxonomic affiliation of 10 isolates from human clinical sources and the environment which phenotypically resembled Alcaligenes faecalis. Here we show that these isolates belong to a novel Ralstonia species for which we propose the name Ralstonia gilardii sp. nov.

\section{METHODS}

Bacterial strains and growth conditions. Strains used in this study are listed in Table 1 . All of the strains were grown aerobically on Trypticase Soy Agar (BBL) and incubated at $37^{\circ} \mathrm{C}$. 
Table 1. List of strains studied

API, Appareils et Procédés d'Identification, Montalieu-Vercieu, France; ATCC, American Type Culture Collection, Manassas, VA, USA; CCUG, Culture Collection, University of Göteborg, Göteborg, Sweden; CDC, Center for Disease Control, Atlanta, GA, USA; LMG, BCCM/LMG Bacteria Collection, Laboratorium voor Microbiologie Gent, Gent, Belgium; NCPPB, National Collection of Plant Pathogenic Bacteria, Sand Hutton, York, UK.

\begin{tabular}{|c|c|c|c|}
\hline $\begin{array}{l}\text { Species and strain } \\
\text { designation }\end{array}$ & $\begin{array}{l}\text { Other strain } \\
\text { designation }\end{array}$ & Depositor & Source (if known) \\
\hline \multicolumn{4}{|l|}{ R. pickettii } \\
\hline LMG $5942^{\mathrm{T}}$ & CCUG $3318^{\mathrm{T}}$ & M. Pickett & Patient after tracheotomy (USA) \\
\hline LMG 7001 & CCUG 3314 & M. Pickett & USA \\
\hline LMG 7002 & CCUG 3316 & M. Pickett & USA \\
\hline LMG 7004 & CCUG 3319 & M. Pickett & USA \\
\hline LMG 7018 & CCUG 3323 & M. Pickett & USA \\
\hline \multicolumn{4}{|l|}{ R. solanacearum } \\
\hline LMG $2299^{\mathrm{T}}$ & NCPPB $325^{\mathrm{T}}$ & NCPPB & Lycopersicon esculentum (USA) \\
\hline LMG 2300 & NCPPB 339 & NCPPB & Solanum tuberosum (Israel) \\
\hline LMG 2303 & NCPPB 789 & NCPPB & Musa sp. (Honduras) \\
\hline LMG 2304 & NCPPB 792 & NCPPB & Tectona grandis (Malaysia, 1959) \\
\hline LMG 17145 & NCPPB 1123 & J. Van Vaerenbergh & Lycopersicon esculentum (New Guinea, 1961) \\
\hline \multicolumn{4}{|r|}{ 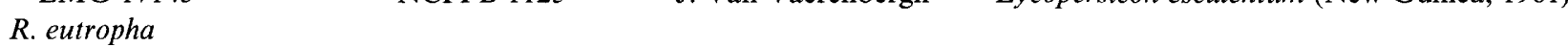 } \\
\hline LMG 1190 & ATCC 33178 & M. Okazaki & Soil (Japan) \\
\hline LMG 1196 & Schlegel N9A & H. Schlegel & \\
\hline LMG $1199^{\mathrm{T}}$ & ATCC $17697^{\mathrm{T}}$ & ATCC & Soil (USA, 1957) \\
\hline LMG 1201 & ATCC 17699 & ATCC & Sludge (Germany, 1962) \\
\hline LMG 1202 & ATCC 17700 & ATCC & Soil (USA, 1957) \\
\hline \multicolumn{4}{|l|}{ R. gilardii } \\
\hline LMG 3399 & API $146-4-76$ & J. Gayral & Furuncle (USA) \\
\hline LMG 3400 & API 119-5-76 & J. Gayral & Human cerebrospinal fluid (USA) \\
\hline LMG $5886^{\mathrm{T}}$ & API $141-2-84^{\mathrm{T}}$ & D. Monget & Whirlpool \\
\hline LMG 5887 & API $142-2-84$ & D. Monget & Whirlpool \\
\hline LMG 5888 & API $143-2-84$ & D. Monget & Whirlpool \\
\hline LMG 5910 & API 188-2-84 & D. Monget & Whirlpool \\
\hline LMG 5913 & API 191-2-84 & D. Monget & Whirlpool \\
\hline LMG 15537 & CCUG 24719 & G. L. Gilardi & Bone marrow (USA) \\
\hline LMG 15540 & CCUG 24724 & G. L. Gilardi & Whirlpool drain (USA, 1984) \\
\hline LMG 15541 & CCUG 24725 & G. L. Gilardi & Human cerebrospinal fluid \\
\hline
\end{tabular}

SDSPAGE of whole-cell proteins. Preparation of whole-cell proteins and SDS-PAGE were performed as described by Pot et al. (1994). Strains were grown for $48 \mathrm{~h}$ at $37^{\circ} \mathrm{C}$. Densitometric analysis, normalization and interpolation of the protein profiles, and numerical analysis were performed using the GelCompar 4.0 software package (Applied Maths).

Fatty acid methyl ester analysis. After an incubation period of $24 \mathrm{~h}$, a loopful of well grown cells was harvested and fatty acid methyl esters were prepared, separated and identified using the Microbial Identification System (Microbial ID) as described by Vandamme et al. (1992).

DNA preparation. High-molecular-mass DNA for DNADNA hybridizations and determination of $\mathrm{G}+\mathrm{C}$ content was prepared using a modified method of Marmur (1961) as described by Vandamme et al. (1992). Alternatively, smallscale DNA extracts were prepared as described by Pitcher $e t$ al. (1989).

AFLP (amplified fragment length polymorphism) fingerprinting. The preparation of template DNA for PCR was performed as described by Huys et al. (1996). One micro- gram of intact chromosomal DNA was digested with $A p a \mathrm{I}$ and TaqI (Pharmacia). After complete digestion, doublestranded restriction-halfsite specific adaptors were ligated to the restriction fragments with T4 ligase (Pharmacia). In the selective PCR amplification, primers B07 (5' GACTGCGTACAGGCCCG 3') and T11 (5' GATGAGTCCTGACCGAG $3^{\prime}$ ) (selective bases at the $3^{\prime}$ end are underlined) were used. B07 was labelled at its $5^{\prime}$ end with a T4 kinase (Pharmacia) assay by using $\left[\gamma_{-}{ }^{32}\right.$ P]ATP (Amersham) as described by Vos et al. (1995). Electrophoresis, visualization of fragments, densitometric scanning and numerical analysis were performed as described by Huys et al. (1996).

165 rDNA sequencing. A fragment of the 16S rRNA gene (corresponding to positions 8-1541 in the Escherichia coli numbering system) of $R$. gilardii LMG $5886^{\mathrm{T}}$ was amplified by PCR using conserved primers (5' AGAGTTTGATCCTGGCTGAG ${ }^{\prime}$ and $5^{\prime}$ AAGGAGGTGATCCAGCCGCA $\left.3^{\prime}\right)$. The PCR products were purified using a QIAquick PCR Purification Kit (Qiagen), according to the manufacturer's instructions. Sequencing was performed using an Applied Biosystems 377 DNA Sequencer and the protocols of the 
Table 2. Sequencing primers

\begin{tabular}{|lllc|}
\hline Name $\dagger$ & Synonym $\ddagger$ & \multicolumn{1}{c|}{ Sequence $\left(\mathbf{5}^{\prime} \rightarrow \mathbf{3}^{\prime}\right)$} & Position $\S$ \\
\hline 16F358 & ${ }^{*}$ Gamma & CTC CTA CGG GAG GCA GCA GT & $339-358$ \\
16F536 & *PD & CAG CAG CCG CGG TAA TAC & $519-536$ \\
16F926 & $*^{*}$ AAC TCA AAG GAA TTG ACG G & $908-926$ \\
16F1112 & $*_{3}$ & AGT CCC GCA ACG AGC GCA AC & $1093-1112$ \\
16F1241 & ${ }^{*}$ R & GCT ACA CAC GTG CTA CAA TG & $1222-1241$ \\
16R339 & Gamma & ACT GCT GCC TCC CGT AGG AG & $358-339$ \\
16R519 & PD & GTA TTA CCG CGG CTG CTG & $536-519$ \\
16R1093 & 3 & GTT GCG CTC GTT GCG GGA CT & $1112-1093$ \\
\hline
\end{tabular}

$\dagger F$, Forward primer; $R$, reverse primer.

$\ddagger$ Forward primers are indicated by ' $*$ '.

$\S E$. coli $16 \mathrm{~S}$ rRNA gene sequence numbering.

manufacturer (Perkin-Elmer) using the ABI Prism Dye Terminator Cycle Sequencing Ready Reaction Kit. The sequencing primers used are listed in Table 2. Sequence assembly was performed by using the program AutoAssembler (Perkin-Elmer). The closest related sequences were found using the FASTA program. Phylogenetic analysis was performed using the GeneCompar 2.1 software package (Applied Maths). The sequences of strains belonging to the same phylogenetic group were retrieved from the EMBL database and aligned with the consensus sequence. A phylogenetic tree was constructed based on the neighbourjoining method.

DNA-DNA hybridizations. The determination of the degree of DNA-DNA binding by using the initial renaturation rate method was performed as described by De Ley et al. (1970). Each value given is the mean of at least two hybridization experiments. The total DNA concentration was $0.059 \mathrm{mM}$ and the optimal renaturation temperature in $2 \times \operatorname{SSC}(1 \times$ SSC is $0.15 \mathrm{M} \mathrm{NaCl}, 0.015 \mathrm{M}$ sodium citrate, $\mathrm{pH} 7.0$ ) was $81^{\circ} \mathrm{C}$.

Determination of $\mathbf{G}+\mathbf{C}$ content. Mean $\mathrm{G}+\mathrm{C}$ values were determined by the thermal denaturation method and were calculated as described by De Ley (1970).

Phenotypic characterization. API microtest systems (API $50 \mathrm{CH}$, API 50AO and API 50AA; bioMérieux) were used to analyse the assimilation of 147 organic compounds as sole carbon sources. The experimental procedure and the reading of the results of the auxanographic tests were performed as described previously (Kersters et al., 1984). Classical phenotypic tests were performed as described previously (Vandamme et al., 1993). API ZYM tests were performed according to the recommendations of the manufacturer (bioMérieux). Flagella staining was done using a solution of tannic acid (2 g), phenol $(5 \%, \mathrm{w} / \mathrm{v}), \mathrm{KAl}\left(\mathrm{SO}_{4}\right)_{2}$ (saturated) in $11 \mathrm{ml}$ saturated crystal violet in $95 \%$ ethanol. Stained strains were viewed under a phase-contrast microscope.

Antimicrobial susceptibility testing. MIC values towards levofloxacin, ciprofloxacin, sparfloxacin, ofloxacin, HMR 3004, HMR 3647, erythromycin A, roxithromycin, clarithromycin and azithromycin were determined by using the agar dilution method conforming to National Committee for Clinical Laboratory Standards (1995) guidelines. Strains were grown on Mueller-Hinton agar (BRL) for 16-20 h at $35^{\circ} \mathrm{C}$.

\section{RESULTS}

\section{SDSPAGE of whole-cell proteins}

Reproducibility was checked by preparing protein extracts in duplicate. The correlation level between the patterns obtained with different extracts of the same strain was more than $93 \%$ (data not shown). After numerical analysis and visual comparison of the profiles, five clusters could be delineated (Fig. 1). Cluster I comprises all $R$. eutropha strains investigated. Cluster II is composed of the $R$. gilardii strains. $R$. solanacearum LMG 2300 and LMG 2303 constitute cluster III. The $R$. pickettii strains investigated comprise cluster IV. $R$. solanacearum LMG 2304 and LMG 17145 constitute cluster V. The type strain of $R$. solanacearum occupied a separate position. Fig. 2 shows the whole-cell protein profiles of a selection of $R$. gilardii, R. eutropha, $R$. pickettii and $R$. solanacearum strains.

\section{Cellular fatty acid analysis}

The cellular fatty acid composition of $R$. gilardii strains and of the type strains of $R$. pickettii, $R$. solanacearum and $R$. eutropha was determined (Table 3 ). In addition, the cellular fatty acid composition of the $A$. faecalis type strain LMG $1229^{\mathrm{T}}$ was available for comparison (P. Vandamme \& M. Vancanneyt, unpublished data). Both quantitative and qualitative differences occur between the taxa examined. The $R$. gilardii strains form a homogeneous group and can easily be distinguished from the other organisms examined, with 17:0 cyclo, 16:0 2-OH and 19:0 cyclo $\omega 8 c$ as most important differential characters.

\section{AFLP fingerprinting}

After selective amplification of template DNA with primers B07 and T11, 40-60 PCR products could be visualized. Reproducibility was checked by preparing PCR products in duplicate and was always higher than $90 \%$ (data not shown). After numerical analysis, four 


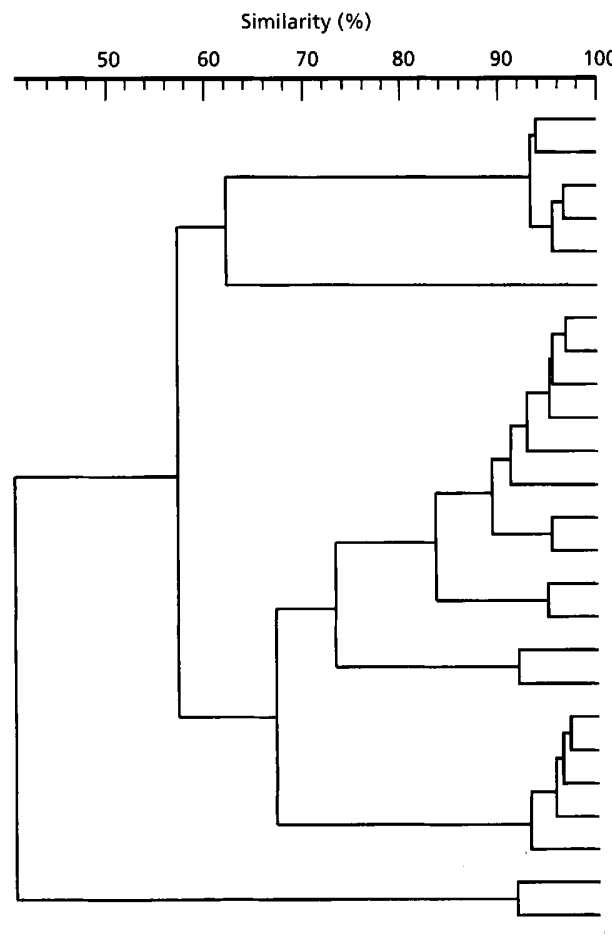

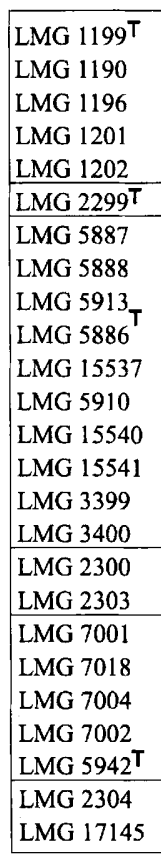

Cluster I

(R. eutropha)

\section{R. solanacearum}

\section{Cluster II}

(R. gilardii)

Cluster III

(R. solanacearum)

Cluster IV

(R. plcketti)

Cluster V

(R. solanacearum)
Fig. 1. Dendrogram derived from the unweighted pair group mean linkage of correlation coefficients between the protein patterns of the strains studied. The correlation coefficient is expressed as percentage similarity for convenience.

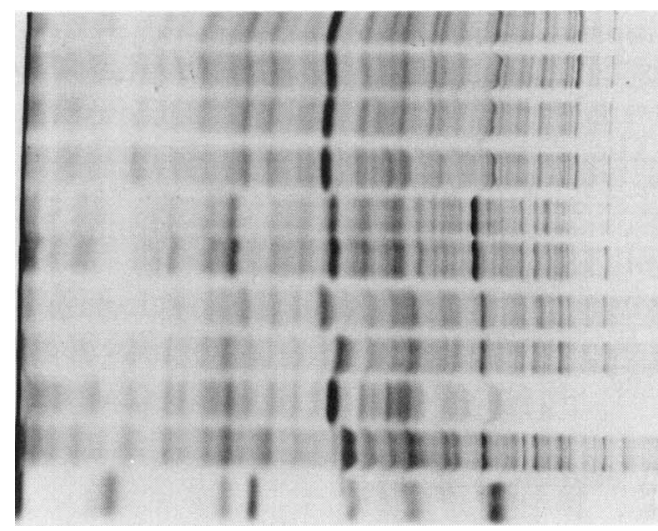

R. gilardii LMG $5886^{\top}$

R. gilardii LMG 5887

R. gilardii LMG 15540

R. gilardii LMG 15541

$R$. eutropha LMG $1199^{\top}$

$R$. eutropha LMG 1203

R. pickettii LMG $5942^{\top}$

$R$. solanacearum LMG $2299^{\top}$

$R$. solanacearum LMG 2300

R. solanacearum LMG 2304
Fig. 2. Electrophoretic protein patterns of a selection of strains investigated. The molecular mass markers used (lane at the bottom) were (from left to right) lysozyme $(14500 \mathrm{Da})$, trypsin inhibitor (20000), trypsinogen (24000), glyceraldehyde-3phosphate dehydrogenase $(36000)$, egg albumin (45000), bovine albumin (60000) and $\beta$-galactosidase (116000).

Table 3. Fatty acid composition of the strains studied

Data are expressed as a percentage. Those fatty acids for which the mean amount for all taxa was less than $1 \%$ are not given. Mean percentages \pm SD are given for $R$. gilardii. TR, Trace amount (less than $1 \%$ ); ND, not detected. Summed feature 1 comprises 14:1 $1 \omega 5 c, 14: 1 \omega 5 t$ or both. Summed feature 3 comprises 14:0 3-OH, 16:1 iso I, an unidentified fatty acid with equivalent chain length value of 10.928, 12:0 ALDE or any combination of these fatty acids. Summed feature 7 comprises 18:1 $\omega 7 c, 18: 1 \omega 9 t$, $18: 1 \omega 12 t$ or any combination of these fatty acids.

\begin{tabular}{|lccccccccccccc}
\hline Strain & $\mathbf{1 2 : 0}$ & $\mathbf{1 4 : 0}$ & $\mathbf{1 6 : 0}$ & $\begin{array}{c}\mathbf{1 7 : 0} \\
\text { cyclo }\end{array}$ & & & & & & & & &
\end{tabular}




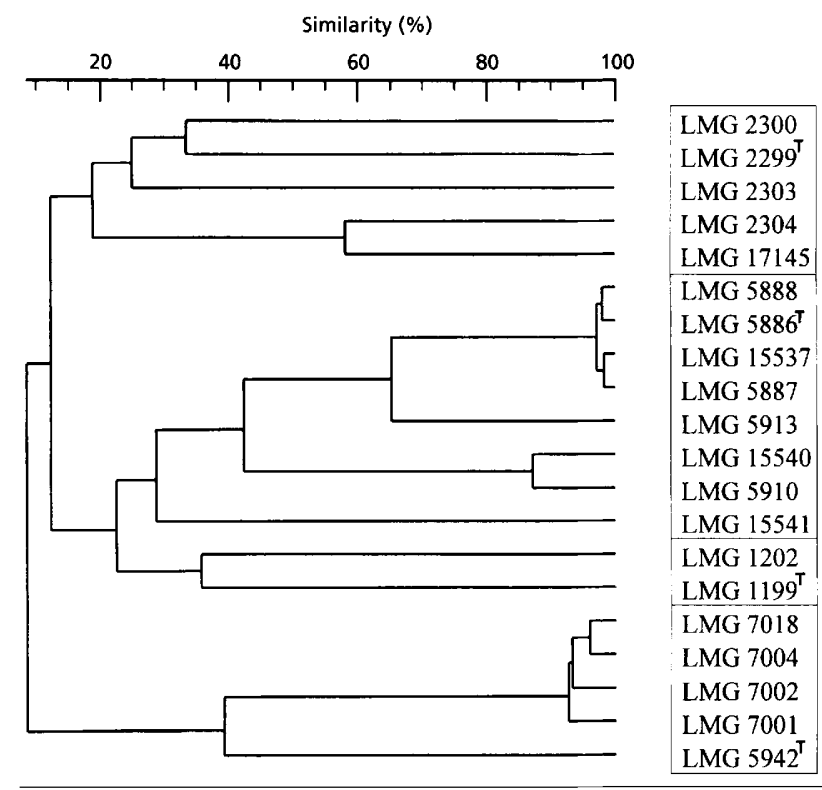

Cluster I

(R. solanacearum)

Cluster II

(R. gilardii)

Cluster III

(R. eutropha)

Cluster IV

(R. pickettii)
Fig. 3. Dendrogram derived from the unweighted pair group mean linkage of correlation coefficients between the AFLP patterns of the strains studied. The correlation coefficient is expressed as percentage similarity for convenience.

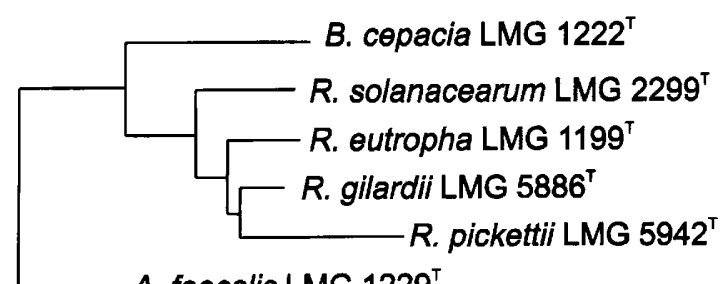

A. faecalis LMG $1229^{\top}$

Fig. 4. Distance matrix tree showing the phylogenetic relationships of Ralstonia species based on 16S rDNA sequence comparisons. Burkholderia cepacia and $A$. faecalis were used as outgroups in this analysis. Bar, $10 \%$ sequence dissimilarity. clusters could be delineated (Fig. 3). Cluster I is composed of the $R$. solanacearum strains investigated, cluster II is composed of $R$. gilardii strains, cluster III is composed of the two R. eutropha strains investigated and cluster IV is composed of $R$. pickettii strains.

\section{$16 S$ rDNA sequencing}

The 16S rRNA gene of $R$. gilardii LMG $5886^{\mathrm{T}}$ shows $97.95 \%$ sequence similarity to the $16 \mathrm{~S}$ rRNA gene of $R$. eutropha LMG $1199^{\mathrm{T}}$ (M32021). The similarity to the $R$. solanacearum LMG 2299 ${ }^{\mathrm{T}}$ (X67036) and $R$. pickettii LMG $5942^{\mathrm{T}}$ (X67042) 16S rRNA genes is 96.16 and $95.48 \%$, respectively. The similarity to

Table 4. Range of MIC values and the MIC for 50 and $90 \%$ of the $R$. gilardii strains investigated

Strains investigated: LMG 5886 ${ }^{\mathrm{T}}$, LMG 5887, LMG 5888, LMG 5910, LMG 5913, LMG 15537 and LMG 15541.

\begin{tabular}{|lccc|}
\hline Antibiotic & Range $\left(\mu \mathrm{g} \mathrm{ml}^{-1}\right)$ & $\mathbf{M I C}_{\mathbf{5 0}}\left(\mu \mathrm{g} \mathrm{ml}^{-1}\right)$ & $\mathbf{M I C}_{\mathbf{9 0}}\left(\mu \mathrm{g} \mathrm{ml}^{-1}\right)$ \\
\hline Levofloxacin & $0 \cdot 25-4$ & 1 & 4 \\
Ciprofloxacin & $0 \cdot 25-4$ & 1 & 4 \\
Ofloxacin & $1-8$ & 2 & 8 \\
Sparfloxacin & $0 \cdot 03-2$ & $0 \cdot 06$ & 2 \\
HMR 3004 & $2-4$ & 2 & 4 \\
HMR 3647 & $1-4$ & 2 & 4 \\
Erythromycin A & $4-16$ & 8 & 16 \\
Roxithromycin & $8-32$ & 16 & 32 \\
Clarithromycin & $4-16$ & 8 & 16 \\
Azithromycin & $0 \cdot 5-2$ & 1 & 2 \\
\hline
\end{tabular}


Table 5. Phenotypic characteristics useful for the differentiation of $R$. gilardii from other Ralstonia species and from $A$. faecalis

Assimilation tests were performed on LMG 5886 ${ }^{\mathrm{T}}$, LMG 5887, LMG 5888, LMG 5910 and LMG 5913; other characteristics were tested on these and three additional strains (LMG 15537, LMG 15540 and LMG 15541) unless specified otherwise. Flagellation was tested on R. gilardii LMG 5886 ${ }^{\mathrm{T}}$, LMG 5910 and LMG 15540; data for the other species are from Yabuuchi et al. (1995). + , More than $90 \%$ of strains gave a positive reaction; - , fewer than $10 \%$ of strains gave a positive reaction; $\mathrm{D}+$, between 10 and $90 \%$ of strains gave a positive reaction and the type strain was positive; $\mathrm{D}-$, between 10 and $90 \%$ of strains gave a positive reaction and the type strain was negative; $v$, between 11 and $79 \%$ of strains gave a positive reaction.

\begin{tabular}{|c|c|c|c|c|c|}
\hline Characteristic & R. gilardii & R. eutropha* & R. pickettii ${ }^{\star}$ & R. solanacearum* & A. faecalis $\dagger$ \\
\hline Catalase activity & + & + & - & + & + \\
\hline Growth at $42^{\circ} \mathrm{C}$ & + & + & + & - & + \\
\hline Growth on $10 \%$ lactose & - & + & + & + & - \\
\hline Nitrate reduction & - & + & + & + & - \\
\hline Nitrite reduction & - & + & + & + & + \\
\hline Denitrification & - & - & + & + & - \\
\hline Urease activity & - & - & + & + & - \\
\hline Growth on $0.5 \% \mathrm{NaCl}$ & + & + & + & - & + \\
\hline Flagellation & One, polar & One-five, peritrich & One, polar & None & Peritrich \\
\hline \multicolumn{6}{|l|}{ Assimilation of: } \\
\hline D-Glucose & - & - & + & + & - \\
\hline D-Galactose & - & - & + & D- & - \\
\hline$p$-Hydroxybenzoate & - & D- & + & D- & - \\
\hline D-Fructose & - & + & + & $\mathrm{D}+$ & - \\
\hline 2-Ketogluconate & - & $\mathrm{D}+$ & + & - & - \\
\hline D-Malate & + & + & - & - & - \\
\hline L-Arabinose & - & - & + & - & - \\
\hline Glucosamine & - & - & + & - & - \\
\hline Aconitate & - & $\mathrm{D}-$ & + & - & $\mathrm{v}$ \\
\hline$n$-Caproate & - & + & + & - & $\mathrm{v}$ \\
\hline L-Cysteine & - & $\mathrm{D}-$ & + & $\mathrm{D}+$ & $\mathrm{v}$ \\
\hline D-Fucose & - & - & + & - & - \\
\hline Mesaconate & + & + & - & - & - \\
\hline Itaconate & + & + & - & - & - \\
\hline D-Xylose & - & - & + & - & - \\
\hline L-Tartrate & - & - & + & $\mathrm{D}-$ & - \\
\hline $\mathrm{N}$-Acetylglucosamine & - & + & + & - & - \\
\hline DL-Norleucine & - & + & - & - & + \\
\hline
\end{tabular}

* Data for assimilation tests from Gillis et al. (1995).

$\dagger$ Data from Kersters \& De Ley (1984).

Burkholderia cepacia LMG 1222 ${ }^{\mathrm{T}}$ (M22518), $A$. faecalis LMG $1229^{\mathrm{T}}(\mathrm{D} 88008)$ and other taxa is below $94 \%$. A dendrogram showing the phylogenetic position of $R$. gilardii is shown in Fig. 4.

\section{DNA-DNA hybridizations}

The level of DNA-DNA binding between $R$. gilardii LMG $5886^{\mathrm{T}}$ and LMG 5910 was $100 \% ; 0 \%$ was found between $R$. gilardii LMG $5886^{\mathrm{T}}$ and $R$. eutropha LMG $1199^{\mathrm{T}}$.

\section{Determination of $\mathbf{G}+\mathbf{C}$ content}

The $\mathrm{G}+\mathrm{C}$ content of strains LMG $5886^{\mathrm{T}}$ and LMG 5910 is 68.3 and $68.1 \mathrm{~mol} \%$, respectively.

\section{Antimicrobial susceptibility testing}

The range of MIC values and the $\mathrm{MIC}_{50}$ and $\mathrm{MIC}_{90}$ of the strains are given in Table 4.

\section{Phenotypic characterization}

The assimilation of carbon substrates, using the microtest systems API $50 \mathrm{CH}$, API $50 \mathrm{AO}$ and API 50AA, was examined for five $R$. gilardii strains: LMG $5886^{\mathrm{T}}$, LMG 5887, LMG 5888, LMG 5910 and LMG 5913. All strains investigated assimilated pyruvate, succinate, glycerol, L- $\alpha$-alanine, acetate, DL-lactate, Lhistidine, L-tyrosine, DL-glycerate, propionate, Lvaline, L-proline, L-serine, L-phenylalanine, DL-3hydroxybutyrate, D-malate, isobutyrate, butyrate, L- 
isoleucine, L-leucine, L-tryptophan, $\beta$-alanine, $n$-valerate, levulinate, pelargonate, caprate, 2-aminobenzoate, azelate, sebacate, glutarate, DL-3-aminobutyrate, pimelate, citraconate, mesaconate, itaconate, isovalerate, sucrose, meso-tartrate, gluconate, fumarate, L-malate, L-aspartate and L-glutamate. None of the strains examined assimilated D-glucose, inositol, Dgalactose, sorbitol, mannitol, trehalose, D-mannose, DL-glycerate, $p$-hydroxybenzoate, DL-4-aminobutyrate, betaine, citrate, 2-ketogluconate, $\mathrm{D}$-fructose, $\mathrm{D}$ arabitol, L-arabinose, D-lyxose, glucosamine, aconitate, L-arginine, $\mathrm{N}$-acetylglucosamine, sarcosine, Lornithine, L-lysine, DL-kynurenine, $n$-caproate, heptanoate, DL-5-aminovalerate, ethanolamine, L-cysteine, dulcitol, D-arabinose, D-tagatose, D-fucose, amygdalin, ribose, malonate, 2-ketoglutarate, DL-2aminobutyrate, L-citrulline, amylamine, arbutin, salicin, diaminobutane, L-rhamnose, 5-ketogluconate, xylitol, L-arabitol, $m$-hydroxybenzoate, butylamine, tryptamine, adonitol, ethylamine, erythritol, oxalate, L-methionine, maleate, D-tartrate, terephthalate, lactose, D-xylose, L-xylose, D-tryptophan, L-mandelate, methyl D-glucoside, D-turanose, o-hydroxybenzoate, glycine, urea, acetamide, D-melibiose, L-tartrate, benzoate, D-cellobiose, benzylamine, histamine, $\beta$-gentiobiose, D-raffinose, spermine, maltose, methyl D-mannoside, D-melezitose, starch, D-mandelate, trigonellin, glycogen, creatine, 3-aminobenzoate, 4-aminobenzoate, phthalate, inulin, methylxyloside, L-sorbose, aesculin or isophthalate.

Classical phenotypic tests and API ZYM tests were performed on eight $R$. gilardii strains (including the type strain), five $R$. pickettii strains, five $R$. solanacearum strains and the type strain of $R$. eutropha. The following features are present in all of the $R$. gilardii strains investigated: oxidase and catalase activity; growth at 30,37 and $42{ }^{\circ} \mathrm{C}$; growth on Drigalski agar; growth in 0.5 and $1.5 \% \mathrm{NaCl}$; alkaline phosphatase, $\mathrm{C}_{4}$-esterase, $\mathrm{C}_{8}$-esterase and leucine-arylamidase. The following features were absent in all of the $R$. gilardii strains investigated: haemolysis and odour on horse blood; fermentation of D-glucose, adonitol, D-fructose and D-xylose; fluorescence on King's B medium; growth on cetrimide agar, $10 \%$ lactose, 4.5 and $6 \%$ $\mathrm{NaCl}$; Tween 80 hydrolysis; amylase and urease activity; nitrate and nitrite reduction; denitrification; liquefaction of gelatine; $\beta$-galactosidase and DNase activity; indole production; growth on acetamide; production of acid or $\mathrm{H}_{2} \mathrm{~S}$ from TSI; $\mathrm{C}_{14}$-lipase, cysteine arylamidase, valine arylamidase, trypsin, chymotrypsin, $\alpha$-galactosidase, $\beta$-galactosidase, $\beta$ glucuronidase, $N$-acetyl- $\beta$-glucosaminidase, $\alpha$-glucosidase, $\beta$-glucosidase, $\alpha$-mannosidase, $\alpha$-fucosidase, tryptophanase and arginine dihydrolase activity. The following features were strain-dependent: tolerance to penicillin $(10 \mu \mathrm{g}$ per disc $)$; motility at $30^{\circ} \mathrm{C}$ and in $\mathrm{O} / \mathrm{F}$ medium; growth on $3.0 \% \mathrm{NaCl}$ and assimilation of $\mathrm{D}-$ $\alpha$-alanine, L-threonine, DL-norvaline, L-norleucine, caprylate, glycolate, maltose, caprate, adipate, citrate and phenylacetate.
Characteristics useful for the differentiation of $R$. gilardii from other Ralstonia species are given in Table 5. Other data are not shown.

\section{DISCUSSION}

We performed a polyphasic taxonomic study to identify 10 strains phenotypically resembling $A$. faecalis (like $A$. faecalis, the strains give negative reactions in a large number of phenotypic tests). Six strains were isolated from whirlpools and four from human clinical samples. The results of this study allowed us to assign all 10 strains to a new species, for which we propose the name $R$. gilardii sp. nov.

\section{Taxonomic position of $R$. gilardii}

Comparison of the 16S rDNA sequence of strain LMG $5886^{\mathrm{T}}$ with those of other species of the $\beta$ Proteobacteria indicated that its closest relative is $R$. eutropha (97.95\% sequence similarity) (Fig. 4). However, DNA-DNA hybridization between LMG $5886^{\mathrm{T}}$ and the $R$. eutropha type strain revealed no significant binding. DNA-DNA hybridizations between strains of other species were not performed as the similarity level between their respective rRNA genes was below $97 \%$ (Stackebrandt \& Goebel, 1994). These data unambiguously indicated that this taxon represents a novel Ralstonia species. Its DNA base ratio of $68-69 \%$ is also within the range of the genus Ralstonia (65-70\%; Yabuuchi et al., 1995).

\section{Differentiation of $\boldsymbol{R}$. gilardii from other Ralstonia species and from $A$. faecalis}

Both whole-cell protein and fatty acid analyses indicate that the $R$. gilardii strains form a homogeneous group which can easily be differentiated from other Ralstonia species (Figs 1 and 2, Table 3). The finding that the $R$. solanacearum strains investigated can be found in two clusters and that the type strain occupied a separate position is remarkable. This heterogeneity is also obvious in Fig. 2.

AFLP is a genomic fingerprinting technique based on the selective amplification of restriction fragments from a total digest of genomic DNA. It has been reported that this method allowed differentiation of Xanthomonas species (Janssen et al., 1996), Aeromonas species (Huys et al., 1996; Janssen et al., 1996) and Acinetobacter species (Janssen et al., 1997) and that its results are generally consistent with DNA-DNA hybridization levels. In this study, all Ralstonia species were easily distinguished (Fig. 3) and the results were in agreement with results obtained by DNA-DNA hybridization (Ralston et al., 1973; this study). The results obtained were also in agreement with $16 \mathrm{~S}$ rRNA sequence analysis, which indicated that $R$. gilardii is most closely related to $R$. eutropha. Interestingly, the low mean linkage level of $R$. solanacearum 
strains (cluster I, $18.7 \pm 3.6 \%$ ) confirms that this species is rather heterogeneous, as reported by Palleroni \& Doudoroff (1971).

Using biochemical tests, $R$. gilardii can be differentiated from $R$. eutropha by its inability to assimilate D-fructose, $n$-caproate, $N$-acetylglucosamine and DLnorleucine, and by the absence of nitrate and nitrite reduction and growth on $10 \%$ lactose. $R$. gilardii can be differentiated from $R$. solanacearum by the assimilation of D-malate, mesaconate and itaconate by the former and D-glucose by the latter. $R$. gilardii can easily be differentiated from $R$. pickettii since the latter is catalase-negative, reduces nitrate and nitrite and is capable of denitrification. Additional characteristics useful for the differentiation of $R$. gilardii from other Ralstonia species are given in Table 5.

In addition, $R$. gilardii can be differentiated from $A$. faecalis by the absence of nitrite reduction and assimilation of DL-norleucine, and by the assimilation of D-malate, mesaconate and itaconate (Kersters \& De Ley, 1984). Differentiation of $R$. gilardii and $A$. faecalis is also possible based on their cellular fatty acid composition, with the presence of 12:0 and absence of $18: 0,16: 1 \omega 7 c$ and $19: 0$ cyclo $\omega 8 c$ fatty acids being characteristic for $A$. faecalis. In addition, the $\mathrm{G}+\mathrm{C}$ content of $A$. faecalis (55.9-59.4 mol \%) is much lower than the $\mathrm{G}+\mathrm{C}$ content of $R$. gilardii (Kersters \& De Ley, 1984).

\section{Description of Ralstonia gilardii sp. nov.}

Ralstonia gilardii (gi.lar'di.i. M.L. gen. n. gilardii in honour of G. L. Gilardi, an American microbiologist who contributed much to our knowledge of Alcaligenes species).

$R$. gilardii cells are Gram-negative, non-sporulating rods that are motile by means of one polar flagellum. Growth is observed at 30,37 and $42{ }^{\circ} \mathrm{C}$. Catalase and oxidase activities are present. Nitrate and nitrite are not reduced. No denitrification. No urease, $\beta$-galactosidase and DNase activity. No liquefaction of gelatin. No aesculin hydrolysis. No indole production. Additional characteristics are listed in Results above. Characteristics differentiating $R$. gilardii from related taxa are summarized in Table 5 . The following fatty acid components are present: 14:0,16:0,17:0 cyclo, $18: 0,16: 1 \omega 7 c, 16: 02-\mathrm{OH}, 19: 0$ cyclo $\omega 8 c$, summed feature 3 and summed feature $7 . \mathrm{G}+\mathrm{C}$ content is between 68 and $69 \mathrm{~mol} \%$. Type strain is LMG $5886^{\mathrm{T}}$ (= API 141-2-84 $4^{\mathrm{T}}$, isolated from a whirlpool. Phenotypic characteristics of the type strain are the same as described above for the species. $\mathrm{G}+\mathrm{C}$ content is $68.3 \mathrm{~mol} \%$. In addition, the type strain does not assimilate adipate, citrate, L-norleucine, DL-norvaline and caprylate but does assimilate caprate, phenylacetate, glycolate, $\mathrm{D}-\alpha$-alanine and L-threonine. All $R$. gilardii strains have been deposited in the BCCM/ LMG Bacteria Collection (Laboratorium voor Micro- biologie Gent, Gent, Belgium) and the CCUG (Culture Collection, University of Göteborg, Göteborg, Sweden).

\section{ACKNOWLEDGEMENTS}

T.C. acknowledges the support received from the Vlaams Instituut voor Bevordering van Wetenschappelijk-technologisch onderzoek in de Industrie (Belgium) in the form of a bursary for advanced study. P.V. and K. K. are indebted to the Fund for Scientific Research-Flanders (Belgium) for a position as a postdoctoral fellow and for research and personnel grants, respectively. We acknowledge the financial support received from the Cystic Fibrosis Trust (UK) (grant RS15) and wish to thank Urbain Torck, Paul Segers and Christine Lammens for excellent technical assistance.

\section{REFERENCES}

De Ley, J. (1970). Re-examination of the association between melting point, buoyant density, and chemical base composition of deoxyribonucleic acid. J Bacteriol 101, 738-754.

De Ley, J., Cattoir, H. \& Reynaerts, A. (1970). The quantitative measurement of DNA hybridization from renaturation rates. Eur J Biochem 12, 133-142.

Gillis, M., Van Van, T., Bardin, R., Goor, M., Hebbar, P., Willems, A., Segers, P., Kersters, K., Heulin, T. \& Fernandez, M. P. (1995). Polyphasic taxonomy in the genus Burkholderia leading to an emended description of the genus and proposition of Burkholderia vietnamiensis $\mathrm{sp}$. nov. for $\mathrm{N}_{2}$-fixing isolates from rice in Vietnam. Int J Syst Bacteriol 45, 274-289.

Huys, G., Coopman, R., Janssen, P. \& Kersters, K. (1996). Highresolution genotypic analysis of the genus Aeromonas by AFLPfingerprinting. Int J Syst Bacteriol 46, 572-580.

Janssen, P., Coopman, R., Huys, G., Swings, J., Bleeker, M., Vos, P., Zabeau, M. \& Kersters, K. (1996). Evaluation of the DNA fingerprinting method AFLP as a new tool in bacterial taxonomy. Microbiology 142, 1881-1893.

Janssen, P., Maquelin, K., Coopman, R., Tjernberg, I., Bouvet, P., Kersters, K. \& Dijkshoorn, L. (1997). Discrimination of Acinetobacter genomic species by AFLP fingerprinting. Int $J$ Syst Bacteriol 47, 1179-1187.

Jenni, B., Realini, L., Aragno, M. \& Tamer, Ü. (1988). Taxonomy of non- $\mathrm{H}_{2}$-lithotrophic, oxalate-oxidizing bacteria related to Alcaligenes eutrophus. Syst Appl Microbiol 10, 126-133.

Kersters, K. \& De Ley, J. (1984). Genus Alcaligenes Castellani and Chalmers 1919, 936 ${ }^{\text {AL }}$. In Bergey's Manual of Systematic Bacteriology, vol. 1, pp. 361-373. Edited by N. R. Krieg \& J. G. Holt. Baltimore: Williams \& Wilkins.

Kersters, K., Hinz, K. H., Hertle, A., Segers, P., Lievens, A., Siegmann, O. \& De Ley, J. (1984). Bordetella avium sp. nov., isolated from the respiratory tracts of turkeys and other birds. Int J Syst Bacteriol 34, 56-70.

McNeill, M. M., Solomon, S. L., Anderson, R. L., Spengler, R. F., Reisberg, B. E., Thornsberry, C. \& Martone, W. J. (1985). Nosocomial Pseudomonas pickettii colonization associated with a contaminated respiratory therapy solution in a special care nursery. J Clin Microbiol 22, 903-907.

Marmur, J. (1961). A procedure for the isolation of deoxyribonucleic acid from micro-organisms. J Mol Biol 3, 208-218.

National Committee for Clinical Laboratory Standards. (1995). Procedure Volume 15, no. 14. Villanova: NCCLS.

Palleroni, N. J. \& Doudoroff, M. (1971). Phenotypic charac- 
terization and deoxyribonucleic acid homologies of Pseudomonas solanacearum. J Bacteriol 107, 690-696.

Pitcher, D. G., Saunders, N. A. \& Owen, R. J. (1989). Rapid extraction of bacterial genomic DNA with guanidium thiocyanate. Lett Appl Microbiol 8, 109-114.

Pot, B., Vandamme, P. \& Kersters, K. (1994). Analysis of electrophoretic whole-organism protein fingerprints. In Chemical Methods in Prokaryotic Systematics, pp. 493-521. Edited by M. Goodfellow \& A. G. O'Donnell. Chichester: Wiley.

Ralston, E., Palleroni, N. J. \& Doudoroff, M. (1973). Pseudomonas pickettii, a new species of clinical origin related to Pseudomonas solanacearum. Int J Syst Bacteriol 23, 15-19.

Riley, P. S. \& Weaver, R. E. (1975). Recognition of Pseudomonas pickettii in the clinical laboratory: biochemical characterisation of 62 strains. J Clin Microbiol 1, 61-64.

Stackebrandt, E. \& Goebel, B. M. (1994). Taxonomic note: a place for DNA-DNA reassociation and 16S rRNA sequence analysis in the present species definition in bacteriology. Int $J$ Syst Bacteriol 44, 846-849.

Taghavi, M., Hayward, C., Sly, L. I. \& Fegan, M. (1996). Analysis of the phylogenetic relationships of strains of Burkholderia solanacearum, Pseudomonas syzygii, and the blood disease bacterium of banana based on $16 \mathrm{~S}$ rRNA gene sequences. Int $J$ Syst Bacteriol 46, 10-15.

Vandamme, P., Vancanneyt, M., Pot, B. \& 10 other authors (1992). Polyphasic taxonomic study of the emended genus Arcobacter with Arcobacter butzleri comb. nov. and Arcobacter skirrowii sp. nov., an aerotolerant bacterium isolated from veterinary specimens. Int J Syst Bacteriol 42, 344-356.

Vandamme, P., Gillis, M., Vancanneyt, M., Hoste, B., Kersters, K. \& Falsen, E. (1993). Moraxella lincolnii sp. nov., isolated from the human respiratory tract, and re-evaluation of the taxonomic position of Moraxella osloensis. Int J Syst Bacteriol 43, 474-481.

Verschraegen, G., Claeys, G., Meeus, G. \& Delanghe, M. (1985). Pseudomonas pickettii as a cause of pseudobacteremia. J Clin Microbiol 21, 278-279.

Vos, P., Hogers, R., Bleeker, M., Reijans, M., van de Lee, T., Hornes, M., Frijters, A., Pot, J., Peleman, J., Kuiper, M. \& Zabeau, M. (1995). AFLP: a new technique for DNA fingerprinting. Nucleic Acids Res 23, 4407-4414.

Yabuuchi, E., Kosako, Y., Yano, I., Hotta, H. \& Nishiuchi, Y. (1995). Transfer of two Burkholderia and an Alcaligenes species to Ralstonia gen. nov.: proposal of Ralstonia pickettii (Ralston, Palleroni and Doudoroff 1973) comb. nov., Ralstonia solanacearum (Smith 1896) comb. nov. and Ralstonia eutropha (Davis 1969) comb. nov. Microbiol Immunol 39, 897-904. 